ISSN 1392-3196 / e-ISSN 2335-8947

Zemdirbyste-Agriculture, vol. 106, No. 4 (2019), p. 315-320

DOI 10.13080/z-a.2019.106.040

\title{
Aluminium leaching response to acid precipitation in a lime-affected soil
}

\author{
Zilvinas KRYZEVICIUS ${ }^{1,2}$, Lina JANUSIENE ${ }^{2}$, Danute KARCAUSKIENE ${ }^{1}$, \\ Alvyra SLEPETIENE ${ }^{3}$, Monika VILKIENE ${ }^{1}$, Audrone ZUKAUSKAITE² \\ ${ }^{1}$ Lithuanian Research Centre for Agriculture and Forestry, Vèžaičiai Branch \\ Gargždų 29, Vèžaičiai, Klaipèda distr., Lithuania \\ E-mail: zilvinas.kryzevicius@lammc.lt \\ ${ }^{2}$ Klaipeda University, Faculty of Marine Technology and Natural Sciences \\ Bijūnų 17, Klaipèda, Lithuania \\ ${ }^{3}$ Lithuanian Research Centre for Agriculture and Forestry, Institute of Agriculture \\ Instituto 1, Akademija, Kèdainiai distr., Lithuania
}

\begin{abstract}
Acid precipitation accelerates acidification process in the soil and facilitates nutrient leaching. The study aimed to explore the effects of long-term liming on aluminium (Al) leaching by comparing a limed soil with an unlimed soil at different acidity $(\mathrm{pH})$ levels of simulated acid rain (SAR). The columns of unlimed and limed soil were watered with SAR at 5.4, 4.7 and $4.0 \mathrm{pH}$ levels. Aluminium was extracted from the solid phase with the following solutions: ammonium oxalate (non-crystalline $\mathrm{Al}$ ), sodium pyrophosphate (organically bound $\mathrm{Al}$ ), copper chloride (organo-Al complexes of low and medium stability), lanthanum chloride (the most labile organo-Al complexes) and ammonium chloride (exchangeable $\mathrm{Al}$ ). The total $\mathrm{Al}$ in the leachate was also determined. Long-term liming had a significant influence on the soil acidity and reduced all $\mathrm{Al}$ compounds in the in solid phase. The $\mathrm{Al}$ concentrations determined in the leachate of the limed soil were $0.12-0.92 \mathrm{mg} \mathrm{L}^{-1}$ and in that of the unlimed soil $-1.63-2.62 \mathrm{mg} \mathrm{L}^{-1}$. Leaching losses of $\mathrm{Al}$ from limed and unlimed soil increased with decreasing acidity of the simulated acid rain. The losses were found to be high when the $\mathrm{pH}$ of SAR was 4.0. Al in the leachate was positively correlated with all $\mathrm{Al}$ fractions in a solid phase and showed this to be one of the reasons for increased Al leaching from acid soils. Al leaching from the soil depended not only on the $\mathrm{pH}$ of simulated acid rain, but also on the soil properties: acidity, Al saturation in the exchange sites (effective cations exchange capacity) and Al compounds in the solid phase of the soil. Limed soil, characterised by a higher buffer capacity (more $\mathrm{Ca}$ and $\mathrm{Mg}$ ), is able to neutralize the effects of acid precipitation and reduce the solubility of Al-containing compounds.
\end{abstract}

Key words: acid deposition, aluminium fractions, liming, soil pH, soluble Al.

\section{Introduction}

Increased deposition of anthropogenic sulphuric $\left(\mathrm{SO}_{2}\right)$ and nitric (NOx) acids has resulted in a dramatic increase in soil acidification worldwide over the last 50 years. Acid rain has the greatest impact on soil acidification and its properties (Bowman et al., 2008). Continuous inputs of proton $\left(\mathrm{H}^{+}\right)$and strong acid anions $\left(\mathrm{SO}_{4}{ }^{2-}\right.$ or $\left.\mathrm{NO}^{3-}\right)$ inevitably accelerate acidification process (Stevens et al., 2009) and facilitate nutrient leaching, which results in ground water pollution and damage to terrestrial and aquatic ecosystems (Ding et al., 2011).

The soil cannot completely neutralize the acidity of rainwater (Behera et al., 2014). Besides, the presence of $\mathrm{SO}_{4}{ }^{2-}$ and $\mathrm{NO}^{3-}$ in acid precipitation promotes leaching of the main cations from the soil (Zhang et al., 2007). Depletion of the main cations reduces soil fertility, causes shortage of plant nutrients (Liu et al., 2007 a), and suppresses chemical resistance of soils and surface waters to acidification (Driscoll et al., 2003). When basic cations are depleted, soil acidity $(\mathrm{pH})$ is mostly buffered by dissolving Al-bearing minerals $(\mathrm{pH}<4.5)(\mathrm{Li}$, Johnson, 2016). It is also important that acid soils have an Al-saturated exchange complex. The occurrence of aluminium (Al) in the soil solution and leaching depend on the acidity as well as on the components capable of discharging this element in the solid fraction of the soil. At $\mathrm{pH}<6.0$, Al solubility is increasing and resulting in the occurrence of a high concentration of toxic Al, which affects plant growth (Driscoll et al., 2003; Xie et al. 2009) and may as well cause an increase in Al concentration in drainage water, which travels further into rivers and seas. Al kills fish and aquatic plants and can be harmful to humans (Ding et al., 2011). Crop yield-limiting mobile $\mathrm{Al}^{3+}$ can be reduced or eliminated by liming (Skuodienè, Repšienè, 2009). Mokolobate and Haynes (2003) have reported that liming reduces the activity of $\mathrm{Al}$ ions (solubility and toxicity). The $\mathrm{pH}$ of acid rain is one of the key factors determining the mobility of metal compounds

Please use the following format when citing the article:

Kryževičius Ž., Janušienė L., Karčauskienė D., Šlepetienė A., Vilkienė M., Žukauskaitė A. 2019. Aluminium leaching response to acid precipitation in a lime-affected soil. Zemdirbyste-Agriculture, 106 (4): 315-320. DOI 10.13080/z-a.2019.106.040 
in the soil (Wang et al., 2009); however, soil properties play an important role as well (Ding et al., 2011).

In the cold and humid zone, where the mean annual precipitation exceeds the mean evapotranspiration, soil acidification is an ongoing natural process. Soil acidification is caused by precipitation (acid rain). In recent years, acid rain with a $\mathrm{pH}$ ranging from 3.9 to 5.4, which dissolves and removes (due to precipitation excess) carbonates in the soil parent material has been occurring in this region. Primary carbonates are leached from more than $2 \mathrm{~m}$ depth in this region (Eidukeviciene et al., 2010). Here, more intense acidification is caused by the heterogeneous, wedge-shaped moraine loam structure and greater age of the soil parent material compared to the surrounding moraine lowlands.

The objective of this work was to study the effects of long-term liming on the leaching of Al by comparing a limed soil with an unlimed soil, both originated from the same parent material and in the same climatic conditions, at different acidity $(\mathrm{pH})$ levels of acidic deposition.

\section{Materials and methods}

Study site. The study site is located in West Lithuania, in the cold and humid zone, where the mean annual precipitation $748 \mathrm{~mm}$ exceeds the mean evapotranspiration $512 \mathrm{~mm}$ and the average annual air temperature is $6.7^{\circ} \mathrm{C}$. This region is strongly affected by the marine climate. Experiments were carried out on a Dystric Endogleyic Glossic Retisol (Loamic, Drainic) (WRB, 2014) developed on a marginal moraine (till)

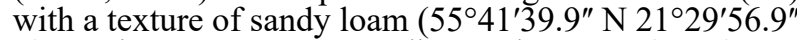
E). Horizon sequence according to the WRB (2014) was Ahp $(0-30 \mathrm{~cm})-\mathrm{E}(30-38 \mathrm{~cm})-\mathrm{E} / \mathrm{B}(38-75 \mathrm{~cm})-\mathrm{B} / \mathrm{E}$ $(75-108 \mathrm{~cm})-\mathrm{BCl}(108-153 \mathrm{~cm})$. The layer of soil carbonates lies deeper than 2 meters below the surface.

Soil collection. The intact soil columns were collected from two different limed soils: unlimed, $0 \mathrm{t} \mathrm{ha}^{-1}$ $\mathrm{CaCO}_{3}$ since 1949 and limed, total amount of $\mathrm{CaCO}_{3}$ applied $104.9 \mathrm{t} \mathrm{ha}^{-1}$ by application of the long-term liming system - primary (1949), repeated (1965) and periodical liming (1985-2005). In 2017, fifteen random samples of soil columns $(11 \mathrm{~cm}$ in inner diameter and $20 \mathrm{~cm}$ in height were selected from each of the plots of unlimed and limed soils. Soil column samples were taken by hammering plastic tubes into the soil from which plant cover had been removed. After soil column sampling, one end of the tube was covered with filter paper. At the bottom of the soil column, a plastic cap with drainage outlet was used.

Soil analysis. The soil samples of collected soil columns were analysed for chemical properties. The samples were dried at $40^{\circ} \mathrm{C}$, sieved at $2 \mathrm{~mm}$, and visible roots and plant residues were removed. The soil acidity $(\mathrm{pH})$ was determined in $1.0 \mathrm{M} \mathrm{KCl}$ at a soil and water ratio of 1:5. Soil organic carbon $\left(\mathrm{C}_{\text {ro }}\right)$ was measured by the Tyurin method modified by Nikitin (Vilkienè et al., 2016) using dichromate oxidation. Effective cations exchange capacity (eCEC) was determined as the sum of exchangeable $\mathrm{Ca}, \mathrm{Mg}, \mathrm{Na}, \mathrm{K}$ and $\mathrm{Al}$ displaced by $1 \mathrm{M}$ $\mathrm{NHCl}$ (Eimil-Fraga et al., 2015). Different forms of aluminium $(\mathrm{Al})$ were extracted from the solid fraction by nonsequential extraction with different reagents: the $\mathrm{Al}$ extracted by $0.2 \mathrm{M}$ acid $\left(\mathrm{NH}_{4}\right)_{2} \mathrm{C}_{2} \mathrm{O}_{4}$ (soil:extractant ratio $1: 100$, with $4 \mathrm{~h}$ shaking in the dark) provides an estimate of the total non-crystalline Al (Alo) (Álvarez et al., 2012); extraction with $0.1 \mathrm{M} \mathrm{Na}_{4} \mathrm{P}_{2} \mathrm{O}_{7}$ (soil:extractant ratio $1: 100$, with $16 \mathrm{~h}$ shaking) estimates the total organically bound Al (Alp) (Zołotajkin et al., 2011); extraction with $\mathrm{CuCl}_{2}$ (soil:extractant ratio 1:10, $30 \mathrm{~min}$ shaking) provides an estimate of organo-Al complexes of low to medium stability (Alcu) (Zołotajkin et al., 2011); extraction with $0.33 \mathrm{M} \mathrm{LaCl}_{3}$ with (soil:extractant ratio $1: 10,2 \mathrm{~h}$ shaking) estimates the most labile organo-Al complexes (Alla) (Eimil-Fraga et al., 2015); Al extracted with unbuffered $1 \mathrm{M} \mathrm{NH}_{4} \mathrm{Cl}$ (soil:extractant ratio 1:20, contact time $12 \mathrm{~h}$ ) is considered readily exchangeable
Al (AlNH) (Álvarez et al., 2012). The extracts with different reagents were filtered and $\mathrm{Al}$ in the extracts was determined by the atomic absorption spectroscopy (Perkin Elmer AAnalyst 100). The difference between Alp and Alcu showed high stability of Al complexes with organic matter (Alp-Alcu); the difference between Alcu and Alla indicated medium stability of Al complexes with organic matter (Alcu-Alla); the difference between Alla and $\mathrm{AlNH}_{4}$ exhibited low stability of Al complexes with organic matter (Alla-AlNH ${ }_{4}$ (Eimil-Fraga et al., 2015). The soil solution was approximated by aqueous extracts (soil:extractant ratio 1:10, the suspension was shaken for $10 \mathrm{~min}$, allowed to rest for three days, filtered at 0.45 $\mu \mathrm{m})$ and total water-soluble $\mathrm{Al}(\mathrm{Alw})$ was determined by visible spectrophotometry following the pyrocatechol violet method (Seco et al., 2014).

Application of simulated acid rain (SAR) to soil column. The experimental design included two soils with three SAR treatments and five replicates. To simulate acid rain, the soil columns were watered with acid solutions at different $\mathrm{pH}$ levels: 5.4, 4.7 and 4.0. The average $\mathrm{pH}$ value of precipitation in Western Lithuania was about 5.4. The respective $\mathrm{pH}$ values of precipitation were achieved by acidifying the naturally collected precipitation water $(\mathrm{pH}=5.4)$ with the addition of a mixture of nitric and sulphuric acids, whose ratio $(1: 4)$ corresponds to that occurring in the naturally formed acid precipitation ( $\mathrm{Li}$ et al., 2015). Soil columns of unlimed and limed soils were watered by simulating rain, every 4 days with $100 \mathrm{ml}$ of respective $\mathrm{pH}$ at a rate of $10 \mathrm{~mL} \mathrm{~min}^{-1}$ to the top of the column every 4 days with a total influent application of 5 times and a total volume of $500 \mathrm{~mL}$ SAR solutions. The leachate percolated through the soil column was collected every 4 days with a container after filtering. In order to estimate the net loss of the chemical components, the volume of the soil solution was measured after watering with SAR. There were no marked differences between the volumes of soil solution during each sampling. The leachate was filtered with a $0.45 \mu \mathrm{m}$ nitrocellulose filter. Chemical components in the solutions were measured as soon as possible. The analytical indicators included solution $\mathrm{pH}$, soluble $\mathrm{Al}$ and dissolved organic carbon (DOC). Soil solution acidity was measured directly with a glass electrode WTW inoLab pH 720 (Gemini BV, The Netherlands). The soluble Al was measured by a standard ISO 10566:1998 (Water quality - Determination of Aluminium - Spectrometric method using pyrocatechol violet). The concentration of DOC was measured with Shimadzu TOC-VCSH (Japan).

Statistical analysis. One-way analysis of variance (ANOVA) was used to compare soil characteristics and Al compounds of unlimed and limed soil. The means were compared by the Fisher's least significant difference test. Principal component analysis (PCA) was performed to examine the relationships between acidity, concentration of $\mathrm{DOC}$ and $\mathrm{Al}$ in the leachate and soil $\mathrm{pH}$ and $\mathrm{Al}$ compounds in the soil. Statistical significance of all results was determined at $P<0.05$. The statistical software package $S A S$ (SAS Inc., USA) was used for all analyses.

\section{Results}

General soil parameters. After long-term liming, the values of soil acidity $(\mathrm{pH})$ (Table 1) increased from 4.1 to 6.7 . In the unlimed soil, the concentration of $\mathrm{C}_{\text {org }}$ was $1.42 \%$. Long-term liming was found to decrease $\mathrm{C}^{\text {org }}$ concentration $(1.12 \%)$. Organic carbon $(\mathrm{C})$ was significantly correlated with $\mathrm{pH}_{\mathrm{KCl}}(r=-0.98, P<0.001)$.

The concentration of exchangeable $\mathrm{Ca}$ was significantly higher $(P<0.001)$ in the limed $\left(3.52 \mathrm{cmol}(+) \mathrm{kg}^{-1}\right)$ than in the unlimed $(0.43 \mathrm{cmol}(+)$ $\left.\mathrm{kg}^{-1}\right)$ soil. Long term liming significantly increased (from 0.07 to $0.22 \mathrm{cmol}(+) \mathrm{kg}^{-1}$ ) the concentrations of exchangeable $\mathrm{Mg}$. The concentration of exchangeable $\mathrm{K}$ was significantly higher in the unlimed $\left(0.28 \mathrm{cmol}(+) \mathrm{kg}^{-1}\right)$ than in the limed $\left(0.27 \mathrm{cmol}(+) \mathrm{kg}^{-1}\right)$ soil. Exchangeable 
Table 1. General parameters of the 0-20 cm layer (average \pm standard deviation) in unlimed and limed soils

\begin{tabular}{|c|c|c|c|c|c|c|c|c|c|}
\hline \multirow{2}{*}{ Soil } & & \multirow{2}{*}{$\mathrm{pH}$} & \multirow{2}{*}{$\underset{\%}{\mathrm{C}_{\mathrm{org}}}$} & $\mathrm{Ca}$ & $\mathrm{Mg}$ & $\mathrm{K}$ & $\mathrm{Na}$ & eCEC & \multirow{2}{*}{$\begin{array}{c}\text { Al saturation } \\
\%\end{array}$} \\
\hline & & & & \multicolumn{5}{|c|}{$\operatorname{cmol}(+) \mathrm{kg}^{-1}$} & \\
\hline Unlimed & mean & 4.1 & 1.42 & 0.43 & 0.07 & 0.28 & 0.11 & 1.63 & 44.9 \\
\hline & SD & 0.05 & 0.004 & 0.009 & 0.001 & 0.003 & 0.020 & 0.167 & 4.33 \\
\hline Limed & mean & 6.7 & 1.12 & $3 ., 52$ & 0.22 & 0.27 & 0.07 & 4.09 & 0.2 \\
\hline & SD & 0.04 & 0.003 & 0.020 & 0.001 & 0.001 & 0.008 & 0.010 & 0.03 \\
\hline
\end{tabular}

Note. eCEC - effective cation exchange capacity; SD - standard deviation; statistically significant differences are among the horizons in the unlimed and limed soil at $P<0.05$.

$\mathrm{Na}$ was significantly higher in the unlimed $(0.11 \mathrm{cmol}(+)$ $\left.\mathrm{kg}^{-1}\right)$ than in the limed $\left(0.07 \mathrm{cmol}(+) \mathrm{kg}^{-1}\right)$ soil. Long-term liming significantly increased the eCEC in the limed soil $\left(4.09 \mathrm{cmol}(+) \mathrm{kg}^{-1}\right)$. The eCEC was positively correlated with soil $\mathrm{pH}(r=0.99, P<0.001)$. The Al saturation $(\%)$ was significantly lower in the limed $(0.2 \%)$ than in the unlimed $(44.9 \%)$ soil. Al saturation was negatively correlated with soil pH $(r=-0.99, P<0.001)$ and eCEC $(r=-0.98, P<0.001)$.
Aluminium (Al) fractions in the solid phase. The total non-crystalline Al (Alo) was $3099 \mathrm{mg} \mathrm{kg}^{-1}$ in the unlimed soil, while in the long-term limed soil the Alo was between $2079 \mathrm{mg} \mathrm{kg}^{-1}$ (Table 2). The Alo was significantly positively correlated with $\mathrm{C}_{\mathrm{org}}(r=0.9388$, $P<0.001)$. The concentration of total organically bound $\mathrm{Al}$ (Alp) was significantly lower in the limed soil $\left(1669 \mathrm{mg} \mathrm{kg}^{-1}\right)$ than in the unlimed soil $\left(2569 \mathrm{mg} \mathrm{kg}^{-1}\right)$. The Alp was significantly negatively correlated with

Table 2. Mean values (and standard deviations) of different forms of aluminium (Al) in solid phase and total Al in solution in unlimed and limed soils $(0-20 \mathrm{~cm}$ layer)

\begin{tabular}{|c|c|c|c|c|c|c|c|c|c|c|}
\hline \multirow{2}{*}{ Soil } & & Alo & Alp & Alcu & Alla & $\mathrm{AlNH}_{4}$ & $\begin{array}{l}\text { Alp- } \\
\text { Alcu }\end{array}$ & $\begin{array}{l}\text { Alcu- } \\
\text { Alla }\end{array}$ & $\begin{array}{c}\text { Alla- } \\
\text { AlNH }_{4} \\
\end{array}$ & \multirow{2}{*}{$\begin{array}{l}\text { Alw } \\
\text { mg L }^{-1}\end{array}$} \\
\hline & & \multicolumn{8}{|c|}{$\mathrm{mg} \mathrm{kg}^{-1}$} & \\
\hline \multirow[t]{2}{*}{ Unlimed } & mean & 3099 & 2569 & 730 & 229.2 & 199.0 & 1839 & 501 & 30.22 & 1.15 \\
\hline & $\mathrm{SD}$ & 223.7 & 149.2 & 53.7 & 23.60 & 25.6 & 136.3 & 59.6 & 15.72 & 0.04 \\
\hline \multirow[t]{2}{*}{ Limed } & mean & 2079 & 1669 & 255 & 2.9 & 1.7 & 1415 & 252 & 1.15 & 0.80 \\
\hline & $\mathrm{SD}$ & 117.0 & 217.5 & 12.5 & 0.22 & 0.2 & 225.9 & 12.4 & 0.24 & 0.02 \\
\hline
\end{tabular}

Note. Alo - the total non-crystalline Al, Alp - the total organically bound Al, Alcu - organo-Al complexes of low to medium stability, Alla - the most labile organo-Al complexes, $\mathrm{AlNH}_{4}$ - exchangeable Al, Alp-Alcu - high stability of Al complexes with organic matter (OM), Alcu-Alla - medium stability of Al complexes with OM, Alla-AlNH 4 - low stability of Al complexes with $\mathrm{OM}, \mathrm{Alw}$ - total water-soluble $\mathrm{Al}$; $\mathrm{SD}$ - standard deviation; statistically significant differences are among the horizons in the unlimed and limed soil profile at $P<0.05$.

$\mathrm{pH}(r=-0.9270, P<0.001)$. The concentration of Al extracted with $\mathrm{CuCl}_{2}$ which estimates the organoAl complexes (Alcu) of low to medium stability was $730 \mathrm{mg} \mathrm{kg}^{-1}$ in the unlimed soil and accounted for $28.4 \%$ of the total organically bound Al. The concentration of Alcu of low to medium stability was $255 \mathrm{mg} \mathrm{kg}^{-1}$ in the limed soil and accounted for $15.3 \%$ of the Alp. The Alcu of low to medium stability were significantly positively correlated with $\mathrm{C} \quad(r=0.39, P=0.032)$, the Alo $(r=0.47, P=0.008)$ and the Alp $(r=0.73, p<0.001)$, negatively correlated with $\mathrm{pH}(r=-0.48, P=0.007)$ and $\operatorname{eCEC}(r=-0.64, P<0.001)$

The concentration of the most labile Al complex was $229.2 \mathrm{mg} \mathrm{kg}^{-1}$ in unlimed and $2.9 \mathrm{mg} \mathrm{kg}^{-1}$ in the limed soil. The organo-Al complexes of high stability totalled $1839 \mathrm{mg} \mathrm{kg}^{-1}$ in unlimed soil, while in the longterm limed soil high stability of Al complexes with organic matter (Alp-Alcu) amounted to $1415 \mathrm{mg} \mathrm{kg}^{-1}$. These results indicated that Alp-Alcu is a predominant form of organically bound Al in an unlimed and limed soil profile, representing in all cases more than $77 \%$ of the organo-Al complexes.

The concentration of organo-Al complexes of medium stability was $501 \mathrm{mg} \mathrm{kg}^{-1}$ in the unlimed soil profile, and the results of long-term limed soil showed that the concentration of medium stability of $\mathrm{Al}$ complexes with organic matter (Alcu-Alla) increased to $252 \mathrm{mg} \mathrm{kg}^{-1}$ (Table 2). These complexes represen $21.15 \%$ of organo-Al complexes in the unlimed soil profile and $15.11 \%$ in the limed soil. Liming significantly reduced organo-Al complexes of medium stability in the soil. Low stability Al complexes with organic matter $\left(\right.$ Alla-AlNH ${ }_{4}$ ) totalled $30.1 \mathrm{mg} \mathrm{kg}^{-1}$ in the unlimed and $1.1 \mathrm{mg} \mathrm{kg}^{-1}$ in the limed soil profile, representing a very low percentage $(<1.3 \%)$ of Al complexes with organic matter. Unlimed soil exhibited a very high concentration of exchangeable Al (199.0 mg kg-1). Liming significantly reduced the exchangeable $\mathrm{Al}$ concentration $\left(1.7 \mathrm{mg} \mathrm{kg}^{-1}\right)$.
The concentration of total water-soluble $\mathrm{Al}$ (Alw) was $1.15 \mathrm{mg} \mathrm{L}^{-1}$ in the limed soil, meanwhile in the unlimed soil profile it was $0.80 \mathrm{mg} \mathrm{L}^{-1}$.

Effect of simulated acid rain (SAR) on chemical parameters of leachate. As shown in Figure 1, leachate $\mathrm{pH}$ changed when soils were treated with different SAR volumes and levels. Application of different SAR levels to naturally acid soil did not exert any effect on the leachate $\mathrm{pH}$, for the treatments applied with SAR at a volume of $400-500 \mathrm{~mL}$.

Al concentration in the leachate was determined not only by the $\mathrm{pH}$ of SAR but also by the $\mathrm{pH}$ of soil (agronomic practice applied - liming), and the results diverged into two groups: in the limed soil -0.12 $0.92 \mathrm{mg} \mathrm{L}^{-1}$ and in the unlimed soil $-1.63-2.62 \mathrm{mg} \mathrm{L}^{-1}$ (Fig. 1). Al concentration in the leachate increased with the increasing volume of SAR, except for the treatment of SAR, whose $\mathrm{pH}$ was 5.4 and 4.7. The opposite trend was identified for DOC concentration in the leachate, which declined with the increasing volume of SAR. The highest DOC leaching (from 51.73 to $24.29 \mathrm{mg} \mathrm{L}^{-1}$ ) occurred when naturally acid soil was watered with SAR, whose $\mathrm{pH}$ was 5.4 , whereas the lowest DOC leaching (from 22.06 to $16.21 \mathrm{mg} \mathrm{L}^{-1}$ ) was recorded at a SAR pH level of 4.0 .

The relationships among leachate properties and $\boldsymbol{A l}$ in the soil. The relationships among leachate properties and Al compounds in the soil are shown in Figure 2. Leachate acidity was positively correlated with soil pH $(r=0.97, P<0.001)$, Ca $(r=0.97, P<0.001)$, $\operatorname{Mg}(r=0.97, P<0.001)$, eCEC $(r=0.97, P<0.001)$ and negatively correlated with $\mathrm{Na}(r=-0.94, P<0.001)$, $\mathrm{K}(r=-0.82, P<0.001)$ and $\mathrm{Al}$ saturation $(r=-0.97$, $P<0.001)$. Meanwhile, leachate $\mathrm{pH}$ was not significantly correlated with different levels of $\operatorname{SAR}(r=0.10$, $P=0.584)$. Leachate $\mathrm{pH}$ was negatively correlated with all $\mathrm{Al}$ fractions in solid phase and $\mathrm{Al}$ in the soil solution: Alo $(r=-0.92, P<0.001)$, Alp $(r=-0.92, P<0.001)$, Alcu $(r=-0.97, P<0.001)$, Alla $(r=-0.96, P<0.001)$, 


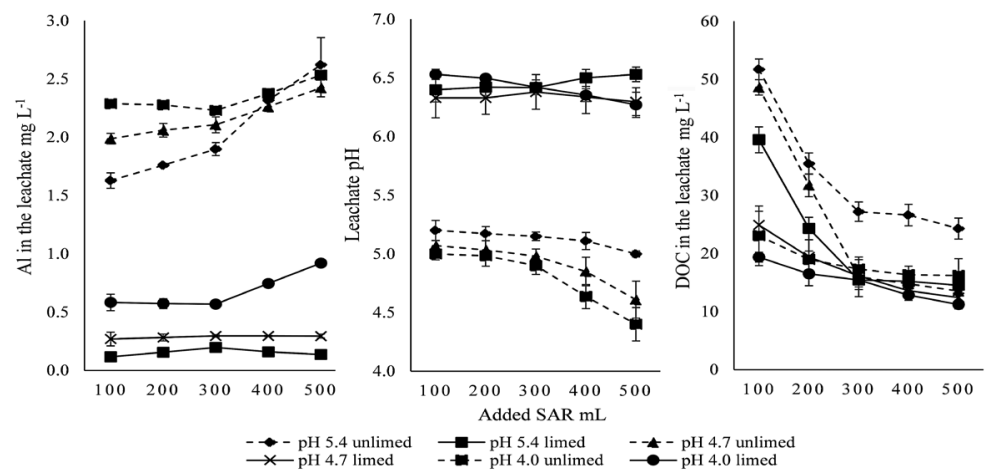

Note. All values are means of five replicates and standard deviations shown as error bars.

Figure 1. Acidity $(\mathrm{pH})$, aluminium $(\mathrm{Al})$ and dissolved organic carbon $(\mathrm{DOC})$ concentrations in the leachate over cumulative volumes of simulated acid rain (SAR)

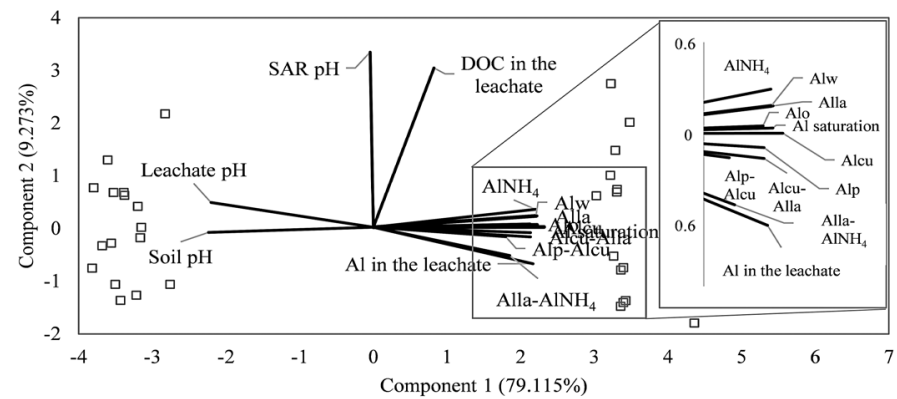

Alo - the total non-crystalline Al, Alp - the total organically bound Al, Alcu - organo-Al complexes of low to medium stability, Alla - the most labile organo-Al complexes, $\mathrm{AlNH}_{4}$ - exchangeable $\mathrm{Al}, \mathrm{Alp}-\mathrm{Alcu}$ - high stability of $\mathrm{Al}$ complexes with organic matter (OM), Alcu-Alla - medium stability of Al complexes with OM, Alla-AlNH ${ }_{4}$ - low stability of Al complexes with $\mathrm{OM}$, Alw - total water-soluble Al; DOC - dissolved organic carbon

Figure 2. Biplot diagram for principal component analysis (PCA) among the soil leachate properties and the aluminium (Al) compounds in the unlimed and limed soils

AlNH $(r=-0.95, P<0.001)$, Alp-Alcu $(r=-0.75$ $P<0.001)$, Alcu-Alla $(r=-0.94, P<0.001)$, Alla-AlNH $(r=-0.84, P<0.001)$ and Alw $(r=0.96, P<0.001)$.

Aluminium concentration in the leachate was negatively correlated with leachate $\mathrm{pH}(r=-0.97$, $P=<0.001)$, soil pH $(r=-0.96, P=<0.001)$, Ca $(r=-0.96, P<0.001), \mathrm{Mg}(r=-0.96, P<0.001)$, eCEC $(r=-0.96, P<0.001)$ and negatively with $\mathrm{Na}(r=0.94$ $P<0.001), \mathrm{K}(r=0.80, P<0.001)$ and $\mathrm{Al}$ saturation $(r=0.96, P<0.001)$ (Fig. 2). Meanwhile, Al in the leachate was not significantly correlated with different levels of SAR $(r=-0.15, P=0.430)$. Al concentration in the leachate was positively correlated with all $\mathrm{Al}$ fractions in solid phase: Alo $(r=0.91, P<0.001)$, Alp $(r=0.89$, $P<0.001)$, Alcu $(r=0.95, P<0.001)$, Alla $(r=0.95$, $P<0.001), \mathrm{AlNH}_{4}(r=0.93, P<0.001)$, Alp-Alcu $(r=0.73$, $P=0.032)$, Alcu-Alla $(r=0.92, P<0.001)$, Alla-AlNH $(r=0.84, P<0.001)$ and Alw $(r=0.94, P<0.001)$.

DOC in the leachate was significantly positively correlated with different levels of SAR $(r=0.44$ $P=0.016)$ and Al fractions: Alcu $(r=0.36, P=0.050)$, Alla $(r=0.43, P=0.0185), \mathrm{AlNH}_{4}(r=0.46, P=0.011)$ and Alw ( $r=0.40, P=0.027)$ (Fig. 2). In contrast, DOC in the leachate was significantly negatively correlated with soil $\mathrm{pH}(r=-0.38, P=0.041)$ and eCEC $(r=-0.38$, $P=0.040)$.

\section{Discussion}

Long-term application of liming resulted in a significant decrease in the exchangeable acidity $\left(\mathrm{pH}_{\mathrm{KCl}}\right)$ of the soil. Skuodienè and Repšienè (2009) have also found that liming increased $\mathrm{pH}_{\mathrm{u}}$ in the arable layer of Retisol. The low $\mathrm{pH}$ of the naturafly acid soil is related to the lack of carbonates in the parent material or the presence of carbonates (in Retisol below $200 \mathrm{~cm}$ ), leaching of bases due to percolation of water in a moderately humid climate (Eidukeviciene et al., 2010). The negative correlation between $\mathrm{Al}$ saturation and eCEC $(r=-0.98, P<0.001)$ showed that the highest effect of liming manifested itself in the layer most affected by the soil formation process, i.e. arable layer.

The content of organic matter decreased in the limed soil as a result of the increase in $\mathrm{pH}$ values caused by liming. This increase of acidity affects the processes of organic matter mineralization in the soil, due to the increase of the microbial activity with the consequent consumption of carbon by soil microorganisms (Seco et al., 2014). Also, this increase of soil $\mathrm{pH}$ affects the leaching of DOC $(r=-0.38$, $P=0.041)$. This may be accounted for by increased solubility of organic matter, intensified microbial activity and increased content of soluble molecules resulting from the decreased soil pH (Filep, Rekasi, 2011). SAR pH was positively correlated with DOC in the leachate $(r=0.44$, $P=0.016$ ), which showed that the alkaline acidity would favour organic matter solubilisation and leaching (Pousada-Ferradás et al., 2012).

Long-term liming generated a significant change in Al compounds in the soil. Regarding the Al fractionation in the solid phase, in soils the total organically bound $\mathrm{Al}(\mathrm{Alp})$ represented no less than $76 \%$ of the total non-crystalline Al (Alo), and this indicates a predominance of organo-Al complexes over inorganic compounds of low crystallinity. This showed that organic matter plays an important role in Al activity in the soil solution (Eimil-Fraga et al., 2015).

Long-term liming reduced the total non-crystalline $\mathrm{Al}$, the organo-Al complexes of different stability as well as the exchangeable $\mathrm{Al}$, in the arable layer. The reduction in the total non-crystalline $\mathrm{Al}$ in the arable layer of limed soil can be explained by the fact that liming reduces the $C$ content (Wang et al., 2014) and consequently diminishes Al complexes with organic matter. Also, this decrease of organic matter positively affects the leaching of DOC and this indicates the positive correlation of DOC in the leachate and organo-Al complexes of low to medium 
stability (Alcu) $(r=0.36, P=0.050)$ and the most labile organo-Al complexes (Alla) $(r=0.43, P=0.019)$. It is noteworthy that despite the reduction of all $\mathrm{Al}$ complexes with organic matter, in percentage terms, liming favoured the formation of high stability complexes in the arable layer; this could be the main effect of decreasing DOC in the leachate (Alvarez et al., 2009).

The results showed a negative relationship between soil $\mathrm{pH}$ and exchangeable Al for the soils. This indicated that $\mathrm{Al}$ competes with base cations for exchange sites of soil under the most acidic conditions, because of the highest solubility of this element at low $\mathrm{pH}$ (Álvarez et al., 2009). Exchangeable Al also correlated negatively with eCEC $(r=-0.42, P=0.022)$, which indicates that the increase of acidity caused by liming favours the appearance of negative charges in the soil components with variable charge (increase in eCEC) and also favours the precipitation of $\mathrm{Al}$ (decrease of exchangeable $\mathrm{Al}$ ) and the increase of basic cations in the exchange sites. Several authors (Álvarez et al., 2009; Skuodienè, Repšienè, 2009) have described a decrease in the exchangeable Al following liming in acid soils.

A decrease in Al in the soil solution was also observed in the arable layer of the limed soil. This is particularly relevant because in this form $\mathrm{Al}$ is most available to plants. Also, this form can be readily leached. However, if environmental conditions vary, solubilized $\mathrm{Al}$ can be reincorporated into the solid phase forming precipitates and/or complexes, or can be bound to exchange sites (Guo et al., 2007; Álvarez et al., 2010).

As observed in this study, leachate $\mathrm{pH}$ was positively correlated with soil $\mathrm{pH}(r=0.97, P<0.001)$, but leachate $\mathrm{pH}$ was not significantly correlated with different levels of SAR $(r=0.10, P=0.584)$ indicating that the highest effect on leachate $\mathrm{pH}$ level is exerted by soil $\mathrm{pH}$. Limed soil had higher eCEC (Table 1), and this indicates that soil with higher eCEC can compensate for the effects of acidic rainfall (Lu et al., 2014). However, with a high input of $\mathrm{H}^{+}$exceeding a certain limit value, the buffering capacity of the soil would be deleted, and acidification of soil and leachate could occur (Qiu et al., 2015), the Al solubility and consequently its leaching would increase.

There was a similar change in the concentration of $\mathrm{Al}$ in the leachate of unlimed soil during the first three times of acid rain addition. However, as the experiment proceeded, the concentrations of Al in the leachate increased under SAR treatments. This could be due to the time needed for the Al to release from a kinetically constrained Al pool to a phase easy to mobilize (Bowman et al., 2008). Other important factor is that soils underwent a transition through different ranges of buffering associated with the weathering and liberation of different elements. Soils were mostly buffered by base cations, but when the base cations on the exchange sites were very low, the Al buffer system dominated to neutralize an increase of acidity (Bowman et al., 2008).

Throughout the experiment, the soluble $\mathrm{Al}$ in the leachate was not affected by SAR $(r=-0.15, P=0.430)$ in unlimed and limed soils. However, other authors have shown that the $\mathrm{Al}$ leaching depends on the $\mathrm{pH}$ (Liu et al., $2007 \mathrm{~b}$ ), but the differences in Al concentration in the leachate between SAR pH treatments were increasingly pronounced in limed soil and tended to increase with increasing the acidity of SAR. This indicated that the cumulative effects of low intensity acidic rainfall addition enhanced the sensitivity of soluble Al to acidic rainfall (Bowman et al., 2008).

Aluminium in the leachate was positively correlated with $\mathrm{Al}$ saturation in exchangeable complex $(r=0.96, P<0.001)$ indicating the existence of higher Al content in the soil solution when the saturation of this element in the exchangeable complex is high. Release of Al to the soil solution (to the soil leachate) may be essential for $\mathrm{pH}$ buffering in very acidic sites, in which exchangeable base cations are scare (Eimil-Fraga et al., 2015 ). The leaching of Al from the soil depends not only on Al saturation or eCEC, but also on the Al form in the solid phase. Al in the leachate was positively correlated with all Al fractions in solid phase (Fig. 2). In this case, Al compounds in the solid phase are strongly affected by long term liming and it showed the negative correlation between soil $\mathrm{pH}$ and $\mathrm{Al}$ forms in the soil.

The reduction of all the forms of $\mathrm{Al}$ in the solid phase and in the solution in the arable layer of the limed soil can be interpreted as a trend towards precipitation of crystalline minerals of Al favoured by the significant increase of acidity and mineralization of organic matter caused by liming. The decrease of this effect resulted in the reduction of Al leaching. Many authors (Meriga et al., 2003; Alvarez et al., 2009; 2012) have indicated that the addition of limestone promotes the removal of $\mathrm{Al}$ from the soil solution, at the same time reduces Al leaching and the precipitation of inorganic non-crystalline or crystalline compounds.

\section{Conclusions}

1. The study found that higher acidity $(\mathrm{pH})$ level of the simulated acid rain (SAR) increased the solubility and mobility of aluminium (Al) compounds in the soil. However, no relationship was found between $\mathrm{Al}$ leaching and $\mathrm{pH}$ of SAR.

2. The division of Al leaching results into two groups showed that Al leaching was most dependent on soil properties: $\mathrm{pH}, \mathrm{Al}$ saturation (eCEC) and content of Al compounds. A limed soil, characterised by a higher buffering capacity, is able to counteract the effects of acids deposited in it and to reduce the solubility of Alcontaining substances.

\section{Acknowledgments}

The paper presents research findings, obtained through the long-term research programme "Productivity and sustainability of agricultural and forest soils" implemented by Lithuanian Research Centre for Agriculture and Forestry.

Received 18032019

Accepted 15072019

\section{References}

1. Álvarez E., Viadé A., Fernández Marcos M. L. 2009. Effect of liming with different sized limestone on the forms of aluminium in a Galician soil (NW Spain). Geoderma, 152: 1-8. https://doi.org/10.1016/j.geoderma.2009.04.011

2. Alvarez E. Fernández-Sanjurjo M. J., Otero X L. Macías F. 2010. Aluminium geochemistry in the bulk and rhizospheric soil of the species colonising an abandoned copper mine in Galicia (NW Spain). Journal of Soils and Sediments, 10: 1236-1245.

https://doi.org/10.1007/s11368-010-0245-z

3. Álvarez E., Fernández-Sanjurjo M. J., Núñez A., Seco N., Corti G. 2012. Aluminium fractionation and speciation in bulk and rhizosphere of a grass soil amended with mussel shells or lime. Geoderma, 173-174: 322-329.

https://doi.org/10.1016/j.geoderma.2011.12.015

4. Behera S., Mallick B., Rautray T. R., Tiwari T. N. Mishra P. C. 2014. Experimental investigations of simulated acid rain affected Brahmi. Advanced Science Letters, 20 (3-4): 862-867. https://doi.org/10.1166/asl.2014.5411

5. Bowman W. D., Cleveland C. C., Halada L., Hreško J., Baron J. S. 2008. Negative impact of nitrogen deposition on soil buffering capacity. Nature Geoscience, 1: 767-770. https://doi.org/10.1038/ngeo339

6. Ding Z., Wang Q., Hu X. 2011. Fractionation of Zn and $\mathrm{Pb}$ in bulk soil and size fractions of water-stable microaggregates of lead/zinc tailing soil under simulated acid rain. Procedia Environmental Sciences, 10 (Part A): 325330. https://doi.org/10.1016/j.proenv.2011.09.053

7. Driscoll C. T., Driscoll K. M., Mitchell M. J., Raynal D.J. 2003. Effects of acidic deposition on forest and aquatic ecosystems in New York State. Environmental Pollution, 123: 327-336. https://doi org/10.1016/S0269-7491(03)00019-8

8. Eidukeviciene M., Volungevicius J., Marcinkonis S., Tripolskaja L., Karcauskiene D., Fullen M. A., Booth C. A 2010. Interdisciplinary analysis of soil acidification hazard and its legacy effects in Lithuania. Natural Hazardsand Earth System Sciences, 10: 1477-1485. https://doi.org/10.5194/nhess-10-1477-2010

9. Eimil-Fraga C., Álvarez-Rodríguez E., Rodríguez-Soalleiro R., Fernández-Sanjurjo M. J. 2015. Influence of parent material 
on the aluminium fractions in acidic soils under Pinus pinaster in Galicia (NW Spain). Geoderma, 255-256: 50-57. https://doi.org/10.1016/j.geoderma.2015.04.026

10. Filep T., Rekasi M. 2011. Factors controlling dissolved organic carbon (DOC), dissolved organic nitrogen (DON) and DOC/DON ratio in arable soils based on a dataset from Hungary. Geoderma, 162 (3-4): 312-318. https://doi.org/10.1016/j.geoderma.2011.03.002

11. Guo J., Zhang X., Vogt R. D., Xiao J., Zhao D., Xiang R., Luo J. 2007. Evaluating main factors controlling aluminum solubility in acid forest soils, southern and Southwestern China. Applied Geochemistry, 22: 388-396. https://doi.org/10.1016/j.apgeochem.2006.11.003

12. Li J., Jia C., Lu Y., Tang S., Shim H. 2015. Multivariate analysis of heavy metal leaching from urban soils following simulated acid rain. Microchemical Journal, 122: 89-95. https://doi.org/10.1016/j.microc.2015.04.015

13. Li W., Johnson C. E. 2016. Relationships among $\mathrm{pH}$, aluminum solubility and aluminum complexation with organic matter in acid forest soils of the Northeastern United States. Geoderma, 271: 234-242.

https://doi.org/10.1016/j.geoderma.2016.02.030

14. Liu J., Zhou G., Zhang D. 2007 (a). Effects of acidic solutions on element dynamics in the monsoon evergreen broad-leaved forest at Dinghushan, China. Environmenta Science and Pollution Research International, 14 (3): 215-218. https://doi.org/10.1065/espr2006.08.337

15. Liu L., Song C. Y., Li F. C. 2007 (b). Release of Si, Al, and $\mathrm{Fe}$ in red soil under simulated acid rain. Huan Jing Ke Xue, 28 (10): 2378-2382 (in Chinese).

16. Lu X., Mao Q., Gilliam F. S., Luo Y., Mo J. 2014. Nitrogen deposition contributes to soil acidification in tropical ecosystems. Global Change Biology, 20 (12): 3790-3801. https://doi.org/10.1111/gcb.12665

17. Meriga B., Reddy B. K., Jogeswar G., Reddy L. A., Kishor P. B. K. 2003. Alleviating effect of citrate on aluminium toxicity of rice (Oryza sativa L.) seedlings. Current Science, 85: 383-386.

18. Mokolobate M. S., Haynes R. J. 2003. A glasshouse evaluation of the comparative effects of organic amendments, lime and phosphate on alleviation of $\mathrm{Al}$ toxicity and $\mathrm{P}$ deficiency in an Oxisol. Journal of Agricultural Science, 140 (4): 409-417. https://doi.org/10.1017/S002185960300323X

19. Pousada-Ferradás Y., Seoane-Labandeira S., MoraGutiérrezA., Núñez-Dẹlgado A. 2012. Risk of water pollution due to ash-sludge mixtures: column trials. International journal of Environmental Science and Technology, 9: 21-29. https://doi.org/10.1007/s13762-011-0014-6
20. Qiu Q., Wu J., Liang G., Liu J., Chu G., Zhou G., Zhang D. 2015. Effects of simulated acid rain on soil and soil solution chemistry in a monsoon evergreen broad-leaved forest in southern China. Environmental Monitoring and Assessment, 187 (5): 272.

https://doi.org/10.1007/s10661-015-4492-8

21. Seco N., Fernández-Sanjurjo M. J., Núñez-Delgado A. Alvarez E. 2014. Spreading of mixtures including wastes from the mussel shell treatment industry on an acid soil: effects on the dissolved aluminium species and on pasture production. Journal of Cleaner Production, 70: 154-163. https://doi.org/10.1016/j.jclepro.2014.02.038

22. Skuodienè R., Repšienè R. 2009. The effects of organic fertilisers and liming on segetal flora in a sustainable crop rotation on an acid soil. Zemdirbyste-Agriculture, 96 (4): 154-169 (in Lithuanian).

23. Stevens C. J., Dise N. B., Gowing D. J. 2009. Regional trends in soil acidification and exchangeable metal concentrations in relation to acid deposition rates. Environment Pollution, 157: 313-319. https://doi.org/10.1016/j.envpol.2008.06.033

24. Vilkienè M., Ambrazaitienè D., Karčauskienė D., Dabkevičius Z. 2016. Assessment of soil organic matter mineralization under various management practices. Acta Agriculturae Scandinavica, Section B: Soil and Plant Science, 66 (8): 641-646.

https://doi.org/10.1080/09064710.2016.1162845

25. Wang D. Z., Jiang X., Rao W., He J. Z. 2009. Kinetics of soil cadmium desorption under simulated acid rain. Ecological Complexity, 6: 432-437.

https://doi.org/10.1016/i.ecocom.2009.03.010

26. Wang X., Cammeraat E. L. H., Cerli C., Kalbitz K. 2014. Soil aggregation and the stabilization of organic carbon as affected by erosion and deposition. Soil Biology and Biochemistry, 72: 55-65. https://doi.org/10.1016/j.soilbio.2014.01.018

27. WRB. 2014. World reference base for soil resources. World Soil Resources Reports 106. FAO, p. 189.

28. Xie Z. Q., Du Y., Zeng Y., Li Y. C., Yan M. L., Jiao S. M. 2009. Effects of precipitation variation on severe acid rain in southern China. Journal of Geographical Sciences, 19: 489-501. https://doi.org/10.1007/s11442-009-0489-y

29. Zhang J., Ouyang Y., Ling D. 2007. Impacts of simulated acid rain on cation leaching from the Latosol in southern China. Chemosphere, 67: 2131-2137.

https://doi.org/10.1016/j.chemosphere.2006.12.095

30. Zołotajkin M., Ciba J., Kluczka J. Skwira M., Smoliński A. 2011. Exchangeable and bioavailable aluminium in the mountain forest soil of Barania Gora range (Silesian Beskids, Poland). Water, Air, Soil, and Pollution, $216(1-4)$ : 571-580. https://doi.org/10.1007/s11270-010-0554-2

ISSN 1392-3196 / e-ISSN 2335-8947

Zemdirbyste-Agriculture, vol. 106, No. 4 (2019), p. 315-320

DOI $10.13080 / \mathrm{z}-\mathrm{a} .2019 .106 .040$

\title{
Rūgščių kritulių poveikis aliuminio išplovimui iš kalkinto dirvožemio
}

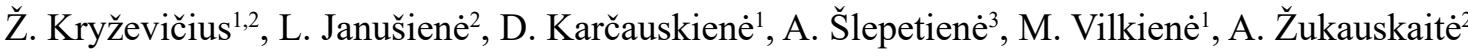 \\ ${ }^{1}$ Lietuvos agrarinių ir miškų mokslų centro Vèžaičių filialas \\ ${ }^{2}$ Klaipèdos universiteto Jūros technologiju ir gamtos mokslų fakultetas \\ ${ }^{3}$ Lietuvos agrarinių ir miškų mokslų centro Žemdirbystės institutas
}

\section{Santrauka}

Rūgštieji krituliai pagreitina dirvožemio rūgštejjimo procesą ir palengvina maisto medžiagų išplovimą. Tyrimo tikslas - ištirti ilgalaikio kalkinimo poveiki aliuminio (Al) išplovimui, veikiant skirtingo pH lygio rūgščiais krituliais. Nekalkintas ir kalkintas dirvožemis buvo laistomas imituotais rūgščiais krituliais, kuriu pH 5,4, 4,7 ir 4,0. Aliuminio junginiai iš kietos dirvožemio fazès buvo ekstrahuoti amonio oksalatu (nekristalinis Al), natrio pirofosfatu (organiškai imobilizuotas Al), vario chloridu (mažo ir vidutinio patvarumo organiniai Al kompleksai), lantano chloridu (labilusis organinis Al) ir amonio chloridu (judrusis Al). Taip pat buvo nustatytas filtrate ištirpęs Al. Ilgalaikis kalkinimas turejo didele itaką dirvožemio $\mathrm{pH}$ rodikliui ir sumažino visu Al junginiu koncentracijas dirvožemio kietojoje fazèje. Nustatytos Al koncentracijos kalkinto dirvožemio filtrate buvo $0,12-0,92 \mathrm{mg} \mathrm{L}^{-1}$, nekalkinto $-1,63-2,62 \mathrm{mg} \mathrm{L}^{-1}$. Al išplovimas kalkintame ir nekalkintame dirvožemyje padidejo mažejant imituojamų rūgščių krituliu pH. Nustatyta, kad didžiausias išplovimas buvo imituojamu rūgščiu krituliu pH esant 4,0. Al koncentracija filtrate teigiamai koreliavo su visais Al junginiais dirvožemio kietojoje fazèje. Al išplovimas iš dirvožemio priklausẻ ne tik nuo imituojamu rūgščiu krituliu pH, bet ir nuo dirvožemio savybių: rūgštumo, Al prisotinimo mainu vietose (efektyvios mainų katijonų talpos), Al junginių koncentracijų bei sudèties dirvožemio kietojoje fazèje. Kalkintas dirvožemis, kurio efektyvi mainų katijonų talpa yra didesnè (turi daugiau $\mathrm{Ca}$ ir $\mathrm{Mg}$ ), gali neutralizuoti rūgščių kritulių poveikị ir sumažinti Al turinčių junginių tirpumą. 